\title{
ФIHAHCOBE ПРАВO
}

\author{
Ігор Оленцер, \\ кандидат юридичних наук, \\ Аокторант кафредри фрінансового права \\ Національного юридичного університету \\ імені Ярослава Муцрого
}

ORCID: 0000-0002-7272-8602

https://doi.org/10.32782/2306-9082/2020-39-14

УДК 342.9

\section{Причини виникнення подвійного оподаткування: теоретичний і практичний аспекти}

Постановка проблеми. Подвійне оподаткування, що виникає внаслідок неоднакового регулювання відносин оподаткування в різних країнах, призводить до надмірного навантаження на платників податків і негативним чином впливає на розвиток транснаціональної економічної співпраці. Одним із шляхів подолання цього негативного явища є укладання державами угод про уникнення подвійного оподаткування, кількість яких у світі постійно зростає. За результатами аналізу літератури можна зробити висновок про наявність кількох тисяч чинних угод про уникнення подвійного оподаткування. Утім, навіть це не убезпечує платників від виявів подвійного оподаткування в окремих випадках, що стає підставою для судового розв’язання спірних питань у судах різних юрисдикцій.

Аналіз останніх досліджень i публікацій. Теоретичним підгрунтям дослідження стали праці іноземних учених-юристів, серед яких варто згадати П. Томпсона, X. Бесерра та інших. Водночас потрібно звернути увагу на різноманітність підходів до причин виникнення подвійного оподаткування.

Постановка завдання. Метою статті є визначення причин, що призводять до подвійного оподаткування, та характеристика практичних аспектів його подолання.

Виклад основного матеріалу. Проблема подвійного оподаткування є актуальною та часто стає причиною звернення платників податків до судів. Єнс Шонфельд, характеризуючи різноманітність виявів подвійного оподаткування, звертає увагу на більшу складність аналізу подвійного оподаткування за основними свободами порівняно із традиційними судовими справами. Таку думку він обгрунтовує тим, що недолік подвійного оподаткування створюється внаслідок одночасного застосування законів більш ніж 
одної податкової юрисдикції. Учений припускає, що в разі визнання Свропейським Судом факту порушення явищем подвійного оподаткування Договору про Європейський Союз він також мав би розв’язати, який із факторів (держава, джерело чи місце проживання) є вирішальним щодо ухвалення рішення про звільнення від подвійного оподаткування [1;2].

Подвійне оподаткування має трансграничний i транснаціональний характер, тому розв'язати його шляхом гармонізації національного податкового законодавства неможливо. На прикладі законодавства країн Свропи, нормативне регулювання у яких $\epsilon$ гармонізованим, стає зрозумілим, що подвійне оподаткування виникає не тільки через відмінність податкових систем держав-членів [3]. Це негативне явище може виникати навіть у разі однакового податкового законодавства всіх держав-членів [2]. Причиною цього є те, що подвійне оподаткування виникає через одночасне виникнення права оподаткування джерела країною-джерелом та права оподаткування резидентів країною проживання. У світлі цього маємо погодитися 3 думкою генерального адвоката Гелхоеда, що «якби в кожній країні існували однакові правила проживання, вони все одно збігалися б, що призвело б до подвійного оподаткування» [4].

Аналізуючи генезу розв'язання проблеми подвійного оподаткування у Європі, варто погодитись із тим, що подвійне оподаткування на міжнародному рівні $є$ перешкодою для розміщення інвестицій за кордоном. Це переконання розвинулося ще 3 епохи Ліги Націй і досі поширене в межах OECP. Зокрема, у Типовій податковій конвенції про доходи та капітал (скорочена версія, липень 2010 р.) щодо подвійного оподаткування зазначається: «Його шкідливий вплив на обмін товарами та послугами та рух капіталів, технологій i людей настільки добре відомий, що навряд чи потрібно наголошувати на важливості усунення перешкод, які подвійне оподаткування створює для розвитку економічних відносин між країнами» [5].

Водночас член Фіскального комітету Персі Томпсон у 1930 р. запропонував таку резолюцію: «Поширеною думкою про те, що небажаний економічний результат, а саме створення штучного бар'єру, що перешкоджає вільному потоку капіталу в канали, у яких його можна найбільш корисно та вигідно використовувати, є подвійне оподаткування, є помилковим: це походження оподаткування є єдиною відповідальністю за цей небажаний економічний результат, який залишився б незмінним, якби всі податки, що базуються на проживанні, було скасовано скрізь, i, як наслідок, подвійне оподаткування припинило існувати» [6, с. 9]. Повторне обговорення цієї пропозиції відбулося через рік після iii висунення, проте Фіскальний комітет дійшов висновку про недостатню аргументацію позиції Персі Томпсона [7, с. 8], який незабаром вийшов із Комітету, унаслідок чого Ліга Націй більше не обговорювала це питання.

Характеризуючи цю ситуацію та підтримуючи твердження Персі Томпсона, Хуан Анхель Бесерра доходить висновку, що оподаткування джерела оподаткування або джерела походження також може не припинятися, оскільки це створило би багато дисбалансів в економіці більшості країн, що розвиваються. Він пише: «Навіть Сполучені Штати здійснювали свій вплив на Фіскальний комітет Ліги націй, щоби зберегти оподаткування походження в Типових конвенціях та надати своїм суб'єктам оподаткування систему відрахувань (еквівалентну сучасній кредитній системі). Оподаткування походження або джерела є необхідним злом. Це також зароджується в самому центрі урядів, де 
домінує бажання оподатковувати іноземця». Судячи з усього, його позиція базується на щорічному рапорті Федеральної торговельної комісії США 1925 року [8, с. 40].

Отже, на переконання Хуана Анхеля Бесерри, податкові договори стосуються розподілу повноважень податкового органу щодо статей доходу, що виробляються сторонами, які $є$ резидентами однієї договірної держави, та отримуються 3 джерел, розташованих в іншій договірній державі. Він пише: «Питання подвійного оподаткування завжди існувало у свідомості людей, які вивчали проблему ще 3 часів Ліги Націй і до сьогодні» [9].

За часів існування Ліги Націй Міжнародна торговельна палата (орган Сполучених Штатів Америки, який мав значний вплив на роботу Ліги Націй) не виказувала занепокоєння щодо оподаткування внутрішніх підприємств підприємств-резидентів. Вектор iï уваги був спрямований на вади регулювання «іноземного оподаткування» транснаціональних компаній. В одному з ії звітів зазначалось: «Щоб уникнути подвійного оподаткування, найкращим засобом буде прийняття місця проживання як основи податку на прибуток» [8, с. 8]. На той час (початок 1920-х років) нагальною проблемою, пов'язаною із розв'язанням питання щодо усунення подвійного оподаткування, стало розширення торгівлі (переважно американських і британських) транснаціональних підприємств.

Характеризуючи подвійне оподаткування, причини його виникнення та наслідки, потрібно порушити й питання ухилення від сплати податків, яке неодмінно постає в разі спроб суб'єктів господарювання зменшити своє податкове навантаження. У літературі воно по-різному описується, але часто висловлюється думка, що основною причиною ухилення від сплати податків (зокрема, і за неналежного врегулювання механізмів усунення подвійного оподаткування) є саме перевищення рівня оподаткування [9].

Висновки. Причинами виникнення явища подвійного оподаткування є не тільки відмінність податкових систем держав, тоді як основною причиною ухилення від сплати податків (зокрема, і за неналежного врегулювання механізмів усунення подвійного оподаткування) $є$ саме перевищення рівня оподаткування. Одним із шляхів подолання негативного явища подвійного оподаткування визначено укладання державами угод про уникнення подвійного оподаткування. Для усунення подвійного оподаткування не досить відмовитися від оподаткування джерела оподаткування або джерела походження, оскільки відсутність такого оподаткування може призвести до виникнення низки дисбалансів в економіці більшості країн, що розвиваються.

\section{Список використаних джерел}

1. Єнс Шонфельд. Doppelbesteuerung undEG-Recht. 2006 STEUER \& WIRTSCHAFT 79, 80 (2006).

2. Думка генерального адвоката Гелхоеда. Справа C-374/04, Test Claiants v. Comm'rs of Inland Revenue, ECR I-11673, 48 (23 лютого 2006 p.). URL: http://curia.europa. eu/juris/showPdf.jsf;jsessionid=62F5D87683B7E541D863307CB5B524EC?text=\&docid= $56203 \&$ pageIndex $=0 \&$ doclang $=$ EN\&mode $=1$ st $\&$ dir $=\&$ occ $=$ first $\&$ part $=1 \&$ cid $=12406132$. $2002 \mathrm{p}$.

3. Справа C-385/00, De Groot v. Staatssecretaris van Financien, ECR I-11819,

4. Georg W. Kofler, Ruth Mason. Double taxation: a European "switch in time?" Columbia journal of European law. 2007, Vol. 14. P. 63-98. URL: http://ssrn.com/ abstract $=979750$. 
5. Model Tax Convention on Income and on Capital - Condensed Version (July 2010). URL: https://www.oecd.org/ctp/treaties/modeltaxconventiononincomeandoncapi tal-condensedversionjuly2010.htm.

6. Annual report of the Federal trade commission for the fiscal year ended June 30, 1930. URL: https://www.ftc.gov/sites/default/files/documents/reports_annual/annualreport-1930/ar1930_0.pdf. C. 9.

7. Annual report of the Federal trade commission for the fiscal year ended June 30, 1931. URL: https://www.ftc.gov/sites/default/files/documents/reports_annual/annualreport-1931/ar1931_0.pdf. C. 8.

8. Annual report of the Federal trade commission for the fiscal year ended June 30, 1925. URL: https://www.ftc.gov/sites/default/files/documents/reports_annual/annualreport-1925/ar1925_0.pdf. C. 40.

9. Juan Angel Becerra Interpretation and Application of Tax Treaties in North America $2^{\text {nd }}$ edition. URL: https://www.ibfd.org/IBFD-Products/Interpretation-and-ApplicationTax-Treaties-North-America-2nd-edition. 2013. 368 p.

Олендер І. Я. Причини виникнення подвійного оподаткування: теоретичний i практичний аспекти

У науковому дослідженні здійснено теоретичний аналіз причин виникнення подвійного оподаткування. Надано характеристику практичних аспектів подолання подвійного оподаткування. Встановлено факт виникнення подвійного оподаткування не тільки через відмінність податкових систем держав. Одним із шляхів подолання негативного явища подвійного оподаткування визначено укладання державами угод про уникнення подвійного оподаткування. У роботі здійснено детальний аналіз праць іноземних учених-юристів із проблематики причин виникнення подвійного оподаткування. Визначено наявність декількох тисяч чинних угод про уникнення подвійного оподаткування. Встановлено, що податкові договори стосуються розподілу повноважень податкового органу щодо статей доходу, що виробляються сторонами, які є резидентами однієї договірної держави, та отримуються з джерел, розташованих в іншій договірній державі, причиною чого $€$ те, що подвійне оподаткування виникає через одночасне виникнення права оподаткування джерела країною-джерелом і права оподаткування резидентів країною проживання. Наголошено на трансграничному та транснаціональному характері подвійного оподаткування. У науковій роботі акцентовано увагу на можливості виникнення явища подвійного оподаткування навіть у разі однакового податкового законодавства всіх держав-членів. Проаналізовано генезу розв'язання проблеми подвійного оподаткування в Європі. Встановлено, що основною причиною ухилення від сплати податків (зокрема, і за неналежного врегулювання механізмів усунення подвійного оподаткування) є саме перевищення рівня оподаткування. Досліджено практичний досвід розв'язання проблеми усунення подвійного оподаткування у країнах Європи. Визначено, що питання ухилення від сплати податків неодмінно постає в разі спроб суб'єктів господарювання зменшити своє податкове навантаження. Наголошено на потребі оподаткування джерела оподаткування або джерела походження, оскільки відсутність такого оподаткування може призвести до виникнення низки дисбалансів в економіці більшості країн, що розвиваються.

Ключові слова: податки, подвійне оподаткування, усунення подвійного оподаткування, податкове законодавство.

Олендер И. Я. Причины возникновения двойного налогообложения: теоретический и практический аспекты

В научном исследовании осуществлен теоретический анализ причин возникновения двойного налогообложения. Охарактеризованы практические аспекты преодоления двойного налогообложения. Установлен факт возникновения двойного налогообложения не только из-за различия налоговых систем государств. Один из путей 
преодоления негативного явления двойного налогообложения определен в заключении государствами соглашений во избежание двойного налогообложения. В работе осуществлен подробный анализ работ иностранных ученых-юристов по проблематике причин возникновения двойного налогообложения. Определено наличие нескольких тысяч действующих соглашений во избежание двойного налогообложения. Установлено, что налоговые договоры касаются распределения полномочий налогового органа по статьям дохода, производятся сторонами, которые являются резидентами одного договаривающегося государства, и получаются из источников, расположенных в другом договорном государстве, причиной чего является то, что двойное налогообложение возникает из-за одновременного возникновения права налогообложения источника страной-источником и права налогообложения резидентов страной проживания. Отмечен трансграничный и транснациональный характер двойного налогообложения. В научной работе акцентировано внимание на возможности возникновения явления двойного налогообложения даже в случае одинакового налогового законодательства всех государств-членов. Проанализирован генезис решения проблемы двойного налогообложения в Европе. Установлено, что основной причиной уклонения от уплаты налогов (в том числе, и при ненадлежащем урегулировании механизмов устранения двойного налогообложения) является именно превышение уровня налогообложения. Исследован практический опыт решения проблемы устранения двойного налогообложения в странах Европы. Определено, что вопрос уклонения от уплаты налогов непременно возникает в случае попыток субъектов хозяйствования уменьшить свою налоговую нагрузку. Отмечена необходимость налогообложения источника налогообложения или источника происхождения, поскольку отсутствие такого налогообложения может привести к возникновению ряда дисбалансов в экономике большинства развивающихся стран.

Ключевъе слова: налоги, двойное налогообложение, устранение двойного налогообложения, налоговое законодательство.

\section{Olender I. Causes of double taxation: theoretical and practical aspects}

The scientific research carried out a theoretical analysis of the causes of double taxation. The characteristics of practical aspects of overcoming double taxation are given. The fact of occurrence of double taxation is established not only because of difference of tax systems of the states. One of the ways to overcome the negative phenomenon of double taxation is the conclusion by states of agreements on avoidance of double taxation. The paper provides a detailed analysis of the works of foreign legal scholars on the causes of double taxation. The existence of several thousand existing agreements on avoidance of double taxation has been determined. It has been established that tax treaties concern the division of powers of the tax authority over items of income produced by parties resident in one Contracting State and derived from sources located in another Contracting State, due to the fact that double taxation arises from the simultaneous occurrence of the right to source taxation source country and the tax rights of residents by country of residence. Emphasis is placed on the cross-border and transnational nature of double taxation. The research focuses on the possibility of double taxation, even in the case of the same tax legislation of all Member States. The genesis of solving the problem of double taxation in Europe is analyzed. It is established that the main reason for tax evasion (including in case of improper regulation of mechanisms for elimination of double taxation) is the excess of the tax rate. The practical experience of solving the problem of eliminating double taxation in European countries is studied. The issue of tax evasion, which inevitably arises in the case of attempts of business entities to reduce their tax burden, has been studied. The need to tax the source or source of taxation is emphasized, as the absence of such taxation can lead to a number of imbalances in the economies of most developing countries.

Key rords: taxes, double taxation, elimination of double taxation, tax legislation. 